\title{
Formation of Humanistic Values of Future Foreign Language Teachers in the Process of Studying Social and Humanitarian Disciplines: Empirical Findings
}

\author{
Vita V. Bezliudna \\ Doctor of Sciences (Pedagogy), Associate Professor, \\ Professor of Foreign Languages Department \\ Pavlo Tychyna Uman State Pedagogical University, Uman, Ukraine \\ Iryna Yu. Shcherban \\ PhD (Pedagogy), Associate Professor, \\ Assistant Professor of Foreign Languages Department \\ Pavlo Tychyna Uman State Pedagogical University, Uman, Ukraine

\section{Olha V. Svyrydiuk} \\ PhD (Pedagogy), Assistant Professor of Foreign Languages Department \\ Pavlo Tychyna Uman State Pedagogical University, Uman, Ukraine

\section{Galyna O. Bondar} \\ PhD (Pedagogy), Associate Professor, \\ Assistant Professor of Foreign Languages Department \\ Pavlo Tychyna Uman State Pedagogical University, Uman, Ukraine
}

Doi: 10.36941/jesr-2020-0o16

\section{Abstract}

The paper is aimed at analysing the current state of humanistic values formation of future foreign language teachers in the process of studying social and humanitarian disciplines. The research was carried out at Pavlo Tychyna Uman State Pedagogical University (Ukraine). The experiment involved 268 students, majoring in 014 Secondary education (Language and literature (English)). The following methods were used: analysis, comparison, classification and systematization of theoretical data, observation, methods of mathematical statistics and complex pedagogical diagnostics, generalisation, etc. The results have showed a low level of humanistic values formation of future foreign language teachers. It is explained by the fact that the disciplines, containing humanistic elements, are studied as separate academic disciplines without their tight correlation and applied format; humanistic potential implementation of social and humanitarian disciplines is not provided in syllabi of those disciplines and information on humanistic ideals is only illustrated. The results of the study reveal the essential difficulties in students' humanistic values formation. The identified difficulties have led authors to the conclusion that there is a need for developing new approaches to improving the process of humanistic values formation in future foreign language teachers by means of social and humanitarian disciplines. The ways to overcome the difficulties have been suggested.

Keywords: humanistic values, future foreign language teachers, levels of values formation, educational environment, social and humanitarian disciplines 


\section{Introduction}

Nowadays the theory of values experiences its revival in connection with new social, scientific and technical realities of life. A general direction of development of modern axiology is marked by the approval of the priority of universal and humanistic principles in the context of different cultures. The categories of human life and life-creation begin to play a crucial role in a new generation's worldview formation.

Professional formation of student youth directly depends on its value priorities. In this connection, humanistic values that are appropriate to the specialists who have chosen the teacher's profession for the humanistic effect of their achievements have been gaining significance. The process of forming humanistic values is considered the basis of the spiritual and moral development of a young person's personality. In this regard, the social and pedagogical issues, connected with the formation of young generation's humanistic values, become crucial for Ukrainian society.

This paper is predominantly based on the works of researchers who provide the issues and results of studies connected with the scope of the problem under consideration: formation of tolerance and humanistic worldview of students based on personality-oriented technology (Beisenbayeva, 2013), humanization of the pedagogical process as the basis of professionally mobile training of a future teacher (Uspanov, 2014), value of humanistic grounds in the field of legal education of youth (Miller, 2015), humanistic sense of creativity in professional university education (Zhuravlyova \& Zhuravlyov, 2015), humanistic foundations of foreign language education (Fedorenko, 2018), formation of humanistic values in future teachers (Kuznetsova, 2001), embodied solutions enabling humanistic moral education (Schwarz-Franco, 2016), concept of judgment for humanistic teaching in a Postmetaphysical age (Kwak, 2015), cultivating responsibility and humanity in public schools through democratic citizenship education (Waghid, 2015), humane attitudes and empathic tendencies (Fung, 2019), argumentation in the University training from a humanistic perspective (Torres, 2019).

Pointing up the topicality of the humanistic vector of modern society development, Fedorenko (2018: 27) believes that humanistic orientations in foreign language education contributing to every student's personality wholeness are of increasing importance in the 21st century. The processes of exploring, understanding and interpreting various sociocultural events, situations are important in the lives of young people encouraging them to reflect on the meaning of life, their place and role in the world through generalising and organising their own experiences.

Additionally, Miller (2015: 428) argues that reconsidering humanism is the main feature of today's mode of thinking. Humanism is as a many-sided and multifold phenomenon, a will for a dialogue, a complex of measures, broadening the outlook of the individuum in its ontological seclusion and natural limitation of the individual, disclosing one human being to another one and creating the attitude of the total openness to the world. This is how the personality rises - a miraculous ability of an individual to comprise in oneself the whole, state, society as a world of culture, and, first of all, the world of a different person. While Uspanov (2014: 5153) indicates that humanity as an individual characteristic expresses firstly the attitude towards others - as the highest social value and secondly orientation at amicability towards people and respect for their proper pride. Under the specific values, together with material, spiritual and social values he understands humanity as an attitude to the pupils' individuality considering it as the highest value. According to Jama (2017: 28) academics should not only focus on cognitive aspects of humane values, but also adopt a humanistic pedagogy by integrating humane values in curricular and co-curricular activities of the academic environment, advance and integrate humane values in the teaching practice.

So, social and cultural needs, the inner world of the students, their vital interests, values, motives are the basis which defines specified understanding of a real life and formation of professional and valuable orientations.

In the present study we consider humanistic values from the point of view of Kuznetsova (2001: 8 ), who regards this concept as a complex of personally significant moral and aesthetic qualities, 
properties, characteristics of real and ideal reality, which correspond to moral and aesthetic universal human ideals.

Nowadays institutions of higher education are to form the following humanistic values of future specialists: kindness - a positive attitude towards people, sincerity in relationships; love for the neighbour - a feeling of deep heartfelt affection, devotion; compassion - the ability to treat understanding, with a pity to human experiences, problems and concerns; justice - the ability to conduct unbiased acts and actions in accordance with the moral and legal norms of society; conscience - human behaviour assimilated with the moral and ethical norms of human community; respect for human dignity - the ability to reveal, develop the best human qualities.

The analysed studies show that the formation of future teachers' humanistic values plays an important role in the process of new generation's worldview development. However, a research gap in this sphere has determined the topic of our investigation.

The aim of the paper is to analyse the current state of formation of humanistic values in future foreign language teachers in the process of social and humanitarian disciplines study. The main objectives are as follows:

- to analyse scientific and methodological literature on the formation of humanistic values of future foreign languages teachers;

- to clarify the essence of the concept "humanistic values";

- to establish criteria for humanistic values formation of future foreign language teachers in the process of social and humanitarian disciplines study;

- to identify mathematical statistics parameters for experimental and control groups, generalized indices of students' humanistic values formation;

- to determine the levels of humanistic values formation of future foreign language teachers.

\section{Methods}

In order to establish the difference between the outgoing and acquired qualitative characteristics of the humanistic values, the methodology of conducting experimental research was developed. The methodological framework of the research included: a) theoretical methods: analysis; comparison; classification and systematization of theoretical data; generalisation (for making conclusions of the future foreign language teachers' humanistic values formation); b) the sociological and pedagogical methods (observation of students' educational and cognitive activity while studying social and humanitarian disciplines, questioning, testing) which allowed to reveal the actual state of professional future foreign language teachers' training; pedagogical experiment (experimental verification of organizational and pedagogical conditions for the formation of the humanistic values of future teachers in the process of the social and humanitarian disciplines study; c) methods of mathematical statistics and complex pedagogical diagnostics (for estimation of the level of humanistic values formation in future foreign language teachers in the process of social and humanitarian disciplines study).

The research was carried out at Pavlo Tychyna Uman State Pedagogical University (Ukraine) and lasted during 2017/2018 academic year (September - May). The experiment involved 268 students majoring in 014 Secondary education (Language and literature (English)).

The number of students chosen for the control and experimental groups was determined according to Sample Size Calculation (Sample Size Calculation, 2018):

Unlimited population $n=\frac{\mathrm{z}^{2} \cdot \hat{\mathrm{p}}(1-\hat{\mathrm{p}})}{\boldsymbol{\varepsilon}^{2}}$,

Finite population $n^{\prime}=\frac{n}{1+\frac{z^{2} \cdot \hat{p}(1-p)}{\varepsilon^{2} N}}$,

where

n and n' - sample size;

$\mathbf{z}$ - the $\mathrm{z}$ score; 


\section{$\varepsilon$ - the margin of error;}

$\mathbf{N}$ - population size;

$\hat{\mathbf{p}}$ - the population proportion.

We find $\mathbf{n}^{\prime}$ with confidence interval (an error) $\varepsilon=10 \%$ used to indicate the reliability of an estimate and a confidence level 0,95 with corresponding z-score $\mathbf{z}=1,96$. Thus,

$$
\begin{aligned}
& n=\frac{(1,96)^{2} \cdot 0,95(1-0,95)}{(0,1)^{2}}=18,2 \\
& n^{\prime}=\frac{18,2}{1+\frac{(1,96)^{2} \cdot 0,95(1-0,95)}{(0,1)^{2} \cdot 268}}=17,04
\end{aligned}
$$

Thus, in order to obtain statistically reliable data, the minimum sample size is not less than $\mathrm{n} \geq 17$ students. We took the working volume of the sample for the experimental group ne $=23$ students and for the control one $\mathrm{nc}=\mathbf{2 4}$. The selection was carried out by the serial selection method. This selection allows us to assess the statistical probability of the study result.

The study of the formation of humanistic values of future foreign language teachers was conducted among full-time students of the first - fourth years.

Training of future foreign language teachers majoring in 014 Secondary education (Language and literature (English)) includes studying disciplines of social and humanitarian cycle which implement the purpose of formation of a system of worldview knowledge, personal positions and valuable orientations of the student. Such disciplines as Sociology, Cultural Studies, History, etc. have significant influence upon this process, the efficiency level of their studying depends on interaction and interrelation of humanitarian knowledge, obtained at higher education institutions.

Paying attention to the fact, that such disciplines as Sociology, Cultural Studies, and History are integral parts of the content of student's humanistic values while studying social and humanitarian disciplines, we stated that the improvement of the system could be essential under condition of determining the level and quality of characteristics of future teachers' humanistic values.

The selection of academic disciplines was connected with the fact that axiological information is focused in the content of certain social and humanitarian disciplines, which are acquired in the form of axiological, valuable, professional knowledge and skills. In the process of studying these disciplines, future teachers obtain experience of creative pedagogical activities, capabilities and practice of assessments and value judgments on the world, people, and future profession.

\section{Results and Discussion}

For achieving the aim of the study, we established the criteria for humanistic values formation. The criteria for assessing the level of the formation of humanistic values were sets of motives, knowledge, skills and abilities of students in the basic philosophical concepts of the study, which were obtained through the social and humanitarian disciplines study. The indices were qualitative manifestations of those criteria, characterized by high, medium and low levels. Each level corresponded to a certain score.

The high level ( 5 points) was proved by clearly expressed interest in humanistic values issues (motivational component); conformity of the acquired knowledge with the individual humanistic ideological settings and the transfer of knowledge in believes of the individual (cognitive component); operational skills that students use in sufficient quantity and that have become steady in their implementation (operational component).

The average level (4 points) was proved by a sufficient interest level in ideological issues (motivational component); insufficiently systematized, not deep knowledge of the concepts associated with the humanist worldview (cognitive component); a sufficient number of operational skills that are implemented in everyday life situations, and sample-based - according to the situation (operational component).

The low level (2-3 points) was proved by poor understanding of humanistic philosophical problems significance (motivational component); superficial knowledge of the interaction "person - 
society" (cognitive component).

To identify the statistically reliable data, further calculations were performed according to the average figures for 2017/2018 academic year for the Faculty of Foreign Languages. The following generalized results were obtained in the experimental and control groups (See Table 1), where the digital characteristics quite typically reflect the state of students' values formation.

Table 1: Generalized indices of the levels of humanistic values formation of future teachers

\begin{tabular}{|c|c|c|c|c|c|c|c|c|c|c|c|c|}
\hline \multirow[b]{4}{*}{$\begin{array}{c}\text { № } \\
\text { task }\end{array}$} & \multicolumn{12}{|c|}{ Disciplines } \\
\hline & \multicolumn{4}{|c|}{ Sociology } & \multicolumn{4}{|c|}{ Cultural Studies } & \multicolumn{4}{|c|}{ History } \\
\hline & \multicolumn{2}{|c|}{$\begin{array}{c}\text { experimental } \\
\text { group }\end{array}$} & \multicolumn{2}{|c|}{$\begin{array}{l}\text { control } \\
\text { group }\end{array}$} & \multicolumn{2}{|c|}{$\begin{array}{c}\text { experimental } \\
\text { group }\end{array}$} & \multicolumn{2}{|l|}{$\begin{array}{l}\text { control } \\
\text { group }\end{array}$} & \multicolumn{2}{|c|}{$\begin{array}{c}\text { experimental } \\
\text { group }\end{array}$} & \multicolumn{2}{|l|}{$\begin{array}{l}\text { control } \\
\text { group }\end{array}$} \\
\hline & $\begin{array}{c}\text { completed } \\
\text { tasks }\end{array}$ & $\%$ & $\begin{array}{c}\text { completed } \\
\text { tasks }\end{array}$ & $\%$ & $\begin{array}{c}\text { completed } \\
\text { tasks }\end{array}$ & $\%$ & $\begin{array}{c}\text { completed } \\
\text { tasks }\end{array}$ & $\%$ & $\begin{array}{c}\text { completed } \\
\text { tasks }\end{array}$ & $\%$ & $\begin{array}{c}\text { completed } \\
\text { tasks }\end{array}$ & $\%$ \\
\hline 1 & 3 & 12,5 & 3 & 12,5 & 4 & 16,7 & 4 & 16,7 & 2 & 8,33 & 3 & 12,5 \\
\hline 2 & 4 & 16,7 & 4 & 16,7 & 2 & 8,33 & 4 & 16,7 & 2 & 8,33 & 5 & 20,8 \\
\hline 3 & 3 & 12,5 & 3 & 12,5 & 2 & 8,33 & 4 & 16,7 & 3 & 12,5 & 4 & 16,7 \\
\hline 4 & 1 & 4,17 & 4 & 16,7 & 3 & 12,5 & 5 & 20,8 & 5 & 20,8 & 2 & 8,33 \\
\hline 5 & 2 & 8,33 & 3 & 12,5 & 4 & 16,7 & 4 & 16,7 & 4 & 16,7 & 2 & 8,33 \\
\hline 6 & 5 & 20,8 & 4 & 16,7 & 5 & 20,8 & 4 & 16,7 & 3 & 12,5 & 4 & 16,7 \\
\hline 7 & 3 & 12,5 & 3 & 12,5 & 6 & 25,0 & 5 & 20,8 & 6 & 25,0 & 5 & 20,8 \\
\hline 8 & 2 & 8,33 & 2 & 8,33 & 6 & 25,0 & 3 & 12,5 & 4 & 16,7 & 3 & 12,5 \\
\hline 9 & 4 & 16,7 & 4 & 16,7 & 5 & 20,8 & 2 & 8,33 & 5 & 20,8 & 4 & 16,7 \\
\hline 10 & 3 & 12,5 & 5 & 20,8 & 5 & 20,8 & 5 & 20,8 & 2 & 8,33 & 5 & 20,8 \\
\hline 11 & 5 & 20,8 & 5 & 20,8 & 5 & 20,8 & 6 & 25,0 & 4 & 16,7 & 6 & 25,0 \\
\hline 12 & 4 & 16,7 & 4 & 16,7 & 4 & 16,7 & 5 & 20,8 & 4 & 16,7 & 4 & 16,7 \\
\hline 13 & 3 & 12,5 & 3 & 12,5 & 3 & 12,5 & 5 & 20,8 & 6 & 25,0 & 6 & 25,0 \\
\hline 14 & 2 & 8,33 & 5 & 20,8 & 5 & 20,8 & 4 & 16,7 & 5 & 20,8 & 5 & 20,8 \\
\hline 15 & 3 & 12,5 & 5 & 20,8 & 2 & 8,33 & 4 & 16,7 & 4 & 16,7 & 2 & 8,33 \\
\hline Mean & & 13,1 & & 15,8 & & 16,9 & & 17,8 & & 16,4 & & 16,7 \\
\hline
\end{tabular}

For the further statistical processing we gave generalized estimations of the levels of values formation of future teachers on the basis of social and humanitarian disciplines study (See Table 2).

Table 2: Distribution of levels of humanistic values formation in social and humanitarian disciplines

\begin{tabular}{|c|c|c|c|c|c|c|c|c|c|c|c|c|c|}
\hline \multirow{4}{*}{ № / tasks } & \multirow{4}{*}{ groups } & \multicolumn{12}{|c|}{ Disciplines } \\
\hline & & \multicolumn{4}{|c|}{ Sociology } & \multicolumn{4}{|c|}{ Cultural Studies } & \multicolumn{4}{|c|}{ History } \\
\hline & & \multicolumn{12}{|c|}{ Evaluation of levels formation } \\
\hline & & 2 & 3 & 4 & 5 & 2 & 3 & 4 & 5 & 2 & 3 & 4 & 5 \\
\hline \multirow[t]{2}{*}{1} & $\mathrm{e}$ & 22 & 1 & - & - & 19 & 4 & - & - & 21 & 2 & - & - \\
\hline & c & 19 & 4 & 1 & - & 21 & 3 & - & - & 20 & 4 & - & - \\
\hline \multirow{2}{*}{2} & $\mathrm{e}$ & 23 & - & - & - & 18 & 5 & - & - & 18 & 5 & - & - \\
\hline & C & 22 & 2 & - & - & 20 & 4 & - & - & 21 & 2 & 1 & - \\
\hline \multirow{2}{*}{3} & $\mathrm{e}$ & 20 & 3 & - & - & 18 & 5 & - & - & 20 & 3 & - & - \\
\hline & C & 20 & 4 & - & - & 18 & 5 & 1 & - & 20 & 4 & - & - \\
\hline \multirow{2}{*}{4} & $\mathrm{e}$ & 21 & 2 & - & - & 19 & 4 & - & - & 22 & 1 & - & - \\
\hline & C & 20 & 4 & - & - & 20 & 4 & - & - & 22 & 2 & - & - \\
\hline \multirow{2}{*}{5} & $\mathrm{e}$ & 23 & - & - & - & 21 & 2 & - & - & 21 & 2 & - & - \\
\hline & C & 20 & 3 & 1 & - & 21 & 3 & - & - & 20 & 4 & - & - \\
\hline \multirow{2}{*}{6} & $\mathrm{e}$ & 18 & 5 & - & - & 20 & 3 & - & - & 19 & 4 & - & - \\
\hline & $\mathrm{C}$ & 22 & 2 & - & - & 20 & 4 & - & - & 21 & 3 & - & - \\
\hline
\end{tabular}




\begin{tabular}{|c|c|c|c|c|c|c|c|c|c|c|c|c|c|}
\hline \multirow{4}{*}{ № / tasks } & \multirow{4}{*}{ groups } & \multicolumn{12}{|c|}{ Disciplines } \\
\hline & & \multicolumn{4}{|c|}{ Sociology } & \multicolumn{4}{|c|}{ Cultural Studies } & \multicolumn{4}{|c|}{ History } \\
\hline & & \multicolumn{12}{|c|}{ Evaluation of levels formation } \\
\hline & & 2 & 3 & 4 & 5 & 2 & 3 & 4 & 5 & 2 & 3 & 4 & 5 \\
\hline \multirow[b]{2}{*}{7} & $\mathrm{e}$ & 19 & 4 & - & - & 17 & 6 & - & - & 23 & - & - & - \\
\hline & C & 21 & 3 & - & - & 19 & 5 & - & - & 19 & 5 & - & - \\
\hline \multirow{2}{*}{8} & $\mathrm{e}$ & 19 & 4 & - & - & 21 & 2 & - & - & 20 & 3 & - & - \\
\hline & C & 23 & 1 & - & - & 21 & 2 & 1 & - & 22 & 2 & - & - \\
\hline \multirow{2}{*}{9} & $\mathrm{e}$ & 20 & 3 & - & - & 19 & 3 & 1 & - & 21 & 2 & - & - \\
\hline & C & 19 & 5 & - & - & 23 & 1 & - & - & 23 & 1 & - & - \\
\hline \multirow{2}{*}{10} & $\mathrm{e}$ & 18 & 4 & 1 & - & 20 & 3 & - & - & 23 & - & - & - \\
\hline & C & 21 & 3 & - & - & 19 & 5 & - & - & 22 & 2 & - & - \\
\hline \multirow{2}{*}{11} & $\mathrm{e}$ & 19 & 4 & - & - & 22 & 1 & - & - & 18 & 4 & 1 & - \\
\hline & C & 22 & 2 & - & - & 20 & 4 & - & - & 20 & 4 & - & - \\
\hline \multirow{2}{*}{12} & $\mathrm{e}$ & 23 & - & - & - & 22 & 1 & - & - & 22 & 1 & - & - \\
\hline & C & 22 & 2 & - & - & 22 & 2 & - & - & 21 & 3 & - & - \\
\hline \multirow{2}{*}{13} & $\mathrm{e}$ & 21 & 2 & - & - & 18 & 5 & - & - & 20 & 3 & - & - \\
\hline & C & 21 & 3 & - & - & 22 & 2 & - & - & 20 & 4 & - & - \\
\hline \multirow{2}{*}{14} & $\mathrm{e}$ & 20 & 3 & - & - & 22 & 1 & - & - & 21 & 2 & - & - \\
\hline & C & 20 & 4 & - & - & 18 & 4 & 2 & - & 19 & 4 & 1 & - \\
\hline \multirow{2}{*}{15} & $\mathrm{e}$ & 20 & 3 & - & - & 20 & 3 & - & - & 20 & 3 & - & - \\
\hline & C & 19 & 5 & - & - & 20 & 4 & - & - & 21 & 3 & - & - \\
\hline
\end{tabular}

Sequence of estimations was presented in the form of series $\mathrm{x}_{1}, \mathrm{x}_{2}, \mathrm{x}_{3}, \mathrm{x}_{4}, \mathrm{x}_{5}$ and, consequently to them, frequency of assessments occurrence $\mathrm{n}_{1}, \mathrm{n}_{2}, \mathrm{n}_{3}, \mathrm{n}_{4}, \mathrm{n}_{5}$ separately for experimental and control groups were presented in the Table 2.

On the basis of data, we determined generalized estimations of students' knowledge and skills in points (arithmetic means) for experimental group:

$$
H_{e}^{o}=\bar{x}_{e}=\frac{1}{n}\left(x_{1} n_{1}+x_{2} n_{2}+x_{3} n_{3}+x_{4} n_{4}+x_{5} n_{5}\right)
$$

and for control group:

$$
H_{c}^{o}=\bar{x}_{c}=\frac{1}{n}\left(x_{1} n_{1}+x_{2} n_{2}+x_{3} n_{3}+x_{4} n_{4}+x_{5} n_{5}\right) \text {, }
$$

where:

$\mathrm{H}_{\mathrm{e}}{ }^{\mathrm{o}}$ - generalized estimator (experimental group);

$\mathrm{H}^{\mathrm{o}}{ }_{\mathrm{c}}$ - generalized estimator (control group);

$\mathrm{x}$ - sample mean;

$\mathrm{x}_{\mathrm{i}}$ - estimations;

$\mathrm{n}_{\mathrm{i}}$ - estimations repetition frequency;

$\mathrm{n}$ - sample number (Sample Mean Formula, 2018).

Using this technique, we found out the level of humanistic values for the students of experimental and control groups on certain disciplines. For statement simplifying and bulk reduction we grouped together and connected similar parameters of the research.

Using the data of Table 2 in accordance with the technique described above, we identified mathematical statistics parameters for experimental and control groups: He, Hc - generalized indices of students' humanistic values formation in the process of social and humanitarian disciplines studying. The results can be seen in Table 3 . 
Table 3: Generalized indices of students' humanistic values formation

\begin{tabular}{|c|c|c|c|c|c|c|c|c|c|c|c|c|c|c|c|c|c|}
\hline \multirow{2}{*}{ Disciplines } & \multirow{2}{*}{ Groups } & \multicolumn{16}{|c|}{ Tasks } \\
\hline & & 1 & 2 & 3 & 4 & 5 & 6 & 7 & 8 & 9 & 10 & 11 & 12 & 13 & 14 & 15 & Mean \\
\hline \multirow{2}{*}{ Sociology } & $\mathrm{He}$ & 2,04 & 2,0 & 2,04 & 2,08 & 2,0 & 2,21 & 2,17 & 2,17 & 2,13 & 2,25 & 2,17 & 2,0 & 2,08 & 2,13 & 2,13 & 2,11 \\
\hline & Hc & 2,25 & 2,08 & 2,17 & 2,17 & 2,21 & 2,08 & 2,13 & 2,04 & 2,21 & 2,13 & 2,08 & 2,08 & 2,13 & 2,17 & 2,21 & 2,14 \\
\hline \multirow{2}{*}{ Cultural Studies } & $\mathrm{He}$ & 2,17 & 2,21 & 2,21 & 2,17 & 2,08 & 2,13 & 2,25 & 2,08 & 2,21 & 2,13 & 2,04 & 2,04 & 2,21 & 2,04 & 2,13 & 2,14 \\
\hline & $\mathrm{Hc}$ & 2,13 & 2,17 & 2,29 & 2,17 & 2,13 & 2,17 & 2,21 & 2,17 & 2,04 & 2,21 & 2,17 & 2,08 & 2,08 & 2,33 & 2,17 & 2,17 \\
\hline \multirow{2}{*}{ History } & $\mathrm{He}$ & 2,08 & 2,21 & 2,13 & 2,04 & 2,08 & 2,17 & 2,0 & 2,13 & 2,08 & 2,0 & 2,25 & 2,04 & 2,13 & 2,08 & 2,13 & 2,1 \\
\hline & Hc & 2,17 & 2,17 & 2,17 & 2,08 & 2,17 & 2,13 & 2,21 & 2,08 & 2,04 & 2,08 & 2,17 & 2,13 & 2,17 & 2,25 & 2,04 & 2,14 \\
\hline
\end{tabular}

The data analysis illustrated a real picture of generalized indices of the levels of students' humanistic values for both groups, where indices of students' humanistic values in the process of Cultural Studies studying were slightly larger than indices of other disciplines. Indices of students' humanistic values formation in experimental group were less than indices of control group in the process of studying: Cultural Studies - by 1,38\%; Sociology - 1,4\%, and History - 1,87\%.

Therefore, average generalized indices of students' humanistic values in experimental and control groups were quite low. They were $2,14(42,8 \%)$ and $2,11(42,2 \%)$ points in Sociology, 2,17 $(43,4 \%)$ and $2,14(42,8 \%)$ points in Cultural Studies, $2,14(42,8 \%)$ and $2,1(42,0 \%)$ points in History respectively.

The figure display allowed to demonstrate patterns of statistical law of indices distribution of appropriate level of humanistic values for chosen disciplines. We marked appropriate level indices of humanistic values in experimental and control groups of students along the abscissa axis at full-scale (fig.1), on Y-axis - the frequencies corresponding to them. We displayed indices of appropriate level of students' humanistic values of both groups on the same graph for illustrative purposes, to make comparative analysis of the obtained results.

Histogram bars were practically identical for both groups and confirmed lack of inherent difference in levels of students' humanistic values in experimental and control groups.

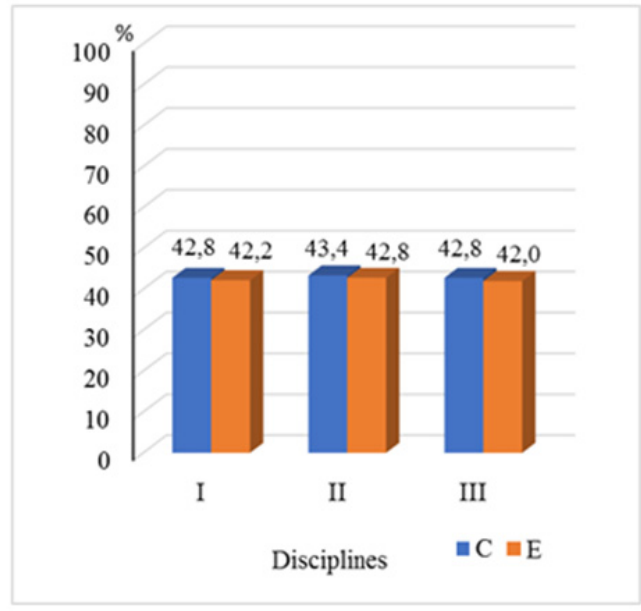

\author{
$E$ - Experimental group; \\ C-Control group; \\ $I$ - Sociology; \\ II-Cultural Studies; \\ III-History.
}

Fig. 1: Histogram of humanistic values indices disposal

On the basis of questionnaire survey and on the results of generalized indices in basic disciplines, represented in Table 2, we defined high, average and low levels of student's formation of humanistic values (See Table 4 ). 
Table 4: Levels of students' humanistic values formation

\begin{tabular}{|l|c|c|}
\hline Levels & $\begin{array}{c}\text { Control group } \\
\%\end{array}$ & $\begin{array}{c}\text { Experimental group } \\
\%\end{array}$ \\
\hline High & - & - \\
\hline Average & $16,5 \pm 1,2$ & $17,9 \pm 1,3$ \\
\hline Low & $83,5 \pm 0,8$ & $82,0 \pm 0,7$ \\
\hline
\end{tabular}

Data, obtained by means of questioning (oral and written questionnaires) as a result of mathematical processing and expert survey of students were taken into consideration. It was determined that low level of future foreign language teachers' formation of humanistic values dominated $(83,5 \%$ - EG; $82,0 \%-C G)$. It can be explained by the fact that the disciplines, containing humanistic elements, were studied as separate academic disciplines without their tight correlation and applied format; humanistic potential implementation of social and humanitarian disciplines was not provided in syllabi of those disciplines and information on humanistic ideals was only illustrated.

Survey results received from students of Faculty of Foreign Languages showed, that one of the main reasons for a low level of humanistic values formation is students' failing to generalize obtained knowledge in social and humanitarian disciplines, and lack of knowledge about using humanistic values in their professional activity. Students considered it necessary to deepen such kind of knowledge and skills in the process of studying social and humanitarian disciplines regarding their necessity in a teaching career. Such knowledge can be one of the preconditions for a stable, rational training in practical humanistic activity.

\section{Conclusions}

In the study course, we have found out that most students do not understand the necessity of humanistic values formation, regarding studentship as a period for qualification obtaining, but not for moral self-education.

The conducted investigation has shown the essential difficulties in students' humanistic values formation:

- the quality of students' humanistic values formation rarely meets the teacher's requirements;

- the level of humanistic values which students get at school is not always taken into consideration in institutions of higher education and, therefore, continuity in its formation is not observed in most cases;

- insufficient level of humanistic competence development of future foreign language teachers;

- inefficient use of activities in the process of humanistic values formation;

- limited use of future foreign language teachers' public activities.

The study has proved that formation of humanistic values of future foreign language teachers needs to be assessed by both the students and the teachers.

The identified difficulties have led us to the conclusion that there is a growing need for developing new ways of improving the process of future foreign language teacher's formation of humanistic values by means of social and humanitarian disciplines. Among the ways to overcome the difficulties are:

- to set up a system of necessary educational conditions (enriched educational environment); the awareness of goals to cultivate moral values that contribute to the student's assimilation of personally and socially important ways of activity;

- to implement a scientifically based program of phased formation of the humanistic values of future foreign language teachers in the process of social and humanitarian disciplines study;

- to create favourable conditions for the formation and development of personality by 
combining the specified professional and personal qualities of each student.

Following on from the results of the study we suggest conducting a quantitative research based on further validation of discussed problem solution. Correlative analysis is recommended on the searching of introduction of new forms and methods of improving the process of humanistic values formation in a future foreign language teacher by means of social and humanitarian disciplines through the introduction of organizational and pedagogical conditions into the teaching and educational process.

\section{References}

Beisenbayeva, A., Ubniyazova, Sh., Bulshekbayeva, A., Kassenova, S., \& Opabekova A. (2013). Formation of tolerance and humanistic worldview of students based on personality-oriented technology. Procedia - Social and Behavioral Sciences, 89, 921-926. DOI: https://doi.org/10.1016/j.sbspro.2013.08.957

Fedorenko, S. (2018). Humanistic Foundations of Foreign Language Education: Theory and Practice. Advanced Education, 10, 27-31. DOI: https://doi.org/10.20535/2410-8286.142319

Fung, S. (2019). Humane Attitudes and Empathic Tendencies in Chinese Young People: Implications for Humane Education. International Education Studies. 12(1), 53. DOI: https://doi.org/10.5539/ies.v12n1p53

Jama, M. (2017). Applying a Humanistic Pedagogy to Advance and Integrate Humane Values in a Medical School Environment. Perspectives in Education, 35(1), 28-39. DOI: http://dx.doi.org/10.18820/2519593X/pie.v35i1.3

Kuznetsova, V. (2001). Formuvannya humanistychnykh tsinnostey u maybutnikh vchyteliv [Formation of humanistic values in future teachers] (Doctoral dissertation, Lugansk State Pedagogical University named after Taras Shevchenko) [Abstract]. [Online] Available: http://www.irbis-nbuv.gov.ua/cgi-bin/irbis_nbuv/cgiirbis_64.exe?

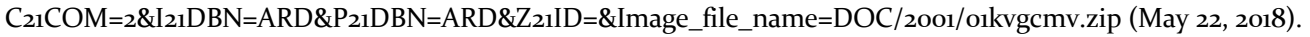

Kwak, D. (2015). The Implications of Arendt's Concept of Judgment for Humanistic Teaching in a Postmetaphysical Age. Educational Theory, 65, 681-697. DOI: https://doi.org/10.1111/edth.12143

Miller, V. (2015). Value of Humanistic Grounds in the Field of Legal Education of Youth. Procedia - Social and Behavioral Sciences, 166, 427-433. DOI: https://doi.org/10.1016/j.sbspro.2014.12.548

Sample Mean Formula. [Online] Available: https://www.statisticshowto.datasciencecentral.com/sample-mean (May 12, 2018).

Sample Size Calculation. [Online] Available: https://www.calculator.net/sample-size-calculator.html. (May 10, 2018).

Schwarz-Franco, O. (2016). Touching the challenge: Embodied solutions enabling humanistic moral education. Journal of Moral Education, 45 (4), 449-464. DOI: https://doi.org/10.1080/03057240.2016.1230052

Torres, R. Vidanovic, A., Viveros, M. (2019). The Argumentation in the University Training from a Humanistic Perspective. Journal of Educational and Social Research, 9 (3), 11-21. DOI: https://doi.org/10.2478/jesr-20190018 .

Uspanov, K., Uzakpayeva, S., \& Bisenbayeva, Z. (2014). Humanization of the Pedagogical Process is the Basis of Professionally Mobile Training of a Future Teacher. Procedia - Social and Behavioral Sciences, 116, 5152-5155. DOI: https://doi.org/10.1016/j.sbspro.2014.01.1090

Waghid, Y. (2015). Cultivating responsibility and humanity in public schools through democratic citizenship education. Africa Education Review, 12(2), 253-265. DOI: https://doi.org/10.108o/18146627.2015.1108003

Zhuravlyova, I., Zhuravlyov, S. (2015). Humanistic Sense of Creativity in Professional University Education: The Role of Creativity in Forming Innovation Model and Modernization of University Training. Procedia - Social and Behavioral Sciences, 206, 445-454. DOI: https://doi.org/10.1016/j.sbspro.2015.10.081 